\title{
MANAJEMEN SKALA PRIORITAS KEHIDUPAN MANUSIA DALAM PERSPEKTIF AGAMA ISLAM
}

\section{MANAGEMENT OF THE PRIORITY SCALE OF HUMAN LIFE IN THE ISLAMIC PERSPECTIVE}

\author{
Satria Kharimul Qolbi \\ Universitas Islam Negeri Sunan Kalijaga Yogyakarta, Indonesia \\ Email: 20204011001@student.uin-suka.ac.id \\ Sutrisno \\ Universitas Islam Negeri Sunan Kalijaga Yogyakarta, Indonesia \\ Email: sutrisno@uin-suka.ac.id
}

\begin{tabular}{l}
\hline Keywords : \\
\hline Management, Priority Scale, \\
Islamic Perspective
\end{tabular}

Kata kunci :

Manajemen, Skala Prioritas, Perspektif Islam

\section{ABSTRACT}

Every human activity has its own role and importance. In this case, a priority scale is required for each activity to be organized on a regular basis. Islam with all forms of teaching provides solutions to every problem of life without exception, as well as in terms of priorities. This research aims to explain the procedures for regulating the scale of priorities in human life according to the foundation of Islamic teachings. To arrive at that goal, the study used a dexatriptive-qualitative method with literature study techniques. In addition, the study also used a thematic approach by collecting Qur'anic verses that addressed a particular topic and ordered it wherever possible. The results of this study show that setting priorities begins with careful planning, solid organizing, proper implementation, and monitoring for control. All these stages are then integrated with the principle of priority jurispruding, namely the measure of truth highlighted in the Qur'an, the main priority over branch priorities, and the priority of people's rights to this right individually.

\begin{tabular}{l}
\hline ABSTRAK \\
\hline Setiap aktivitas manusia memiliki peran dan kepentingan masing- \\
masing. Dalam hal ini, skala prioritas diperlukan agar setiap aktivitas \\
tersusun secara teratur. Agama Islam dengan segala bentuk \\
pengajarannya memberikan solusi bagi setiap permasalahan hidup \\
tanpa terkecuali, begitu juga dalam hal prioritas. Penelitian ini \\
bertujuan untuk menjelaskan tata cara mengatur skala prioritas dalam \\
kehidupan manusia menurut fondasi ajaran Islam. Untuk sampai \\
pada tujuan tersebut, penelitian ini menggunakan metode deksriptif- \\
kualitatif dengan teknik studi kepustakaan. Selain itu, penelitian ini \\
juga menggunakan pendekatan tematik dengan mengumpulkan ayat- \\
ayat Al-Qur'an yang membahas topik tertentu dan menertibkannya \\
sedapat mungkin. Hasil penelitian ini menunjukkan bahwa mengatur \\
prioritas diawali dengan perencanaan yang matang, \\
pengorganisasian yang solid, pelaksanaan yang tepat, lalu \\
monitoring untuk pengendalian. Seluruh tahapan ini kemudian \\
diintegrasikan dengan prinsip fikih prioritas, yaitu ukuran kebenaran \\
yang disorot dalam Al-Qur'an, prioritas pokok atas prioritas cabang, \\
dan prioritas hak masyarakat atas hak inidividu.
\end{tabular}


Diterima: 4 September 2021; Direvisi: 22 Oktober 2021; Disetujui: 6 Desember 2021 Tersedia online: 10 Desember 2021

How to cite: Satria Khakimul Qolbi, Sutrisno, "Manajemen Skala Prioritas Kehidupan Manusia dalam Perspektif Agama Islam", NUKHBATUL 'ULUM: Jurnal Bidang Kajian Islam Vol. 7, No. 2 (2021): 197-210. doi: 10.36701/nukhbah.v7i2.357.

\section{PENDAHULUAN}

Dalam KBBI Offline 1.2., kata "prioritas" merupakan hal yang didahulukan atau diutamakan, sedangkan "memprioritaskan" berarti mendahulukan atau mengutamakan sesuatu daripada yang lain. Setiap manusia dalam kegiatannya tidak luput dari prioritas ketika dalam satu waktu menemukan kegiatan atau acara yang bersifat urgen maupun terencana. "Skala" merupakan garis atau titik tanda yang berderet-deret sama jaraknya yang digunakan untuk mengukur termometer, lajur untuk menentukan tingkatan atau banyaknya sesuatu serta perbandingan ukuran besarnya gambaran dengan keadaan sebenarnya1. "Skala prioritas" berarti memiliki susunan kegiatan yang urut sesuai kepentingan dan urgensinya, sehingga terdapat acuan dalam perbuatan dan tindakan yang menjadi dasar kegiatan tersebut.

Skala prioritas sangatlah penting bagi setiap kehidupan manusia. Pada umumnya, manusia memiliki aktivitas kegiatan yang berbeda-beda dan kegiatan tersebut memiliki tanggung jawab dan konsekuensi tersendiri, sehingga dalam mengatur aktivitas memiliki prioritas yang utama dalam menjalankannya. Pada kasus-kasus tertentu, skala prioritas dirangkai dan diwujudkan dalam bentuk sebuah aturan seperti aturan tempat duduk penumpang kereta api diprioritaskan kepada wanita hamil, orang tua, orang cacat, dan ibu membawa anak pada peraturan ini disebut TDP atau payung hukum tempat duduk prioritas. Hal ini mengatur manusia untuk dapat mengetahui skala prioritasnya saat menjadi penumpang kereta, akan tetapi pada berita yang dipublikasikan oleh tirto.id menyatakan bahwa masih banyak pemuda-pemudi yang masih melanggar dengan duduk di kursi prioritas padahal hal tersebut tidak dibenarkan ${ }^{2}$. Dengan demikian, kasus ini menunjukkan betapa kurangnya kesadaran pada diri manusia dalam mengatur skala prioritas.

Fenomena ini terdapat pada semua ranah kehidupan sesuai kebutuhan masingmasing, baik pada ranah pendidikan, ekonomi, sosial, maupun kebutuhan sehari-hari lainnya. Prioritas pendidikan sendiri merupakan proses yang menentukan usaha dalam mencerdaskan manusia dalam upaya pengajaran dan pelatihan sehingga jelas usaha prosesnya $^{3}$. Dari segi ekonomi, tentu menciptakan peningkatan perekonomian sehingga kemiskinan di negara ini berkurang, lalu meningkatkan produksi sehingga mengurangi impor dan memaksimalkan sumber daya sendiri, menjadi prioritas. Dari segi sosial, mewujudkan masyarakat toleran di tengah-tengah masyarakat multikultur

\footnotetext{
${ }^{1}$ Dendy Sugono, Kamus Bahasa Indonesia (Jakarta: Pusat Bahasa, 2008). h. 1364

2 Aditya Widya Putri, "Empati Diatas Tempat Duduk Prioritas KRL," Tirto.Id, November 11, 2016. h. 2

${ }^{3}$ Celly Beto, "Prioritas Pendidikan Tahun 2021, Menurut Menteri Pendidikan Dan Kebudayaan Nadiem Makarim," https:/www.depoedu.com/2020/08/31/edu-talk/prioritas-pendidikan-tahun-2021menurut-mentri-pendidikan-dan-kebudayaan-nadiem-

makarim/\#: :text=Prioritas\%20Pendidikan\%20adalah\%20proses\%20penentuan,target\%20pendidikan $\% 20$ akan\%20dapat\%20tercapai., 2020.
} 
baik dari segi perbedaan agama maupun perbedaan suku dan ras, juga seharusnya menjadi prioritas. Problem-problem tersebut tentu memiliki skala prioritas tersendiri, sehingga perlu adanya arahan yang tepat agar sasaran parameternya jelas untuk proses keutamaannya. Sebagai umat beragama Islam, tentu tolok ukur dalam menentukan skala prioritas adalah dengan menggunakan corak ajaran Islam.

Dalam pandangan Islam, skala prioritas diatur sedemikian rupa agar umat Islam dapat mengukur parameter prioritasnya. Yusuf Qardhawi berpendapat bahwa meletakkan segala sesuatu harus dilakukan seduai dengan peringkatnya, secara adil, dari segi hukum, nilai, dan pelaksanaannya. Pekerjaan yang mula-mula dikerjakan harus didahulukan, berdasarkan penilaian syariat yang sahih, yang diberi petunjuk oleh cahaya wahyu, dan diterangi oleh akal. Sesuatu yang tidak penting, tidak didahulukan atas sesuatu yang penting. Sesuatu yang penting tidak didahulukan atas sesuatu yang lebih penting. Sesuatu yang tidak kuat (marjuh) tidak didahulukan atas sesuatu yang kuat (rajih). Artinya, setiap perkara mesti diletakkan di tempatnya masing-masing, yang seimbang dan lurus, tidak lebih dan tidak kurang 4 .

Setiap permasalahan yang berkaitan dengan prioritas tentu harus memiliki parameter dalam mengukur seberapa penting hal tersebut harus didahulukan, sehingga disinilah titik pentingnya suatu pandangan agama dalam mengatur skala prioritas. Tuntunan agama yang jelas akan membentuk suatu petunjuk arah bagi manusia, khususnya umat Islam dalam mengatur skala prioritasnya berdasarkan fondasi AlQur'an dan hadis. Kedua sumber pokok inilah yang menjadi acuan utama dalam menyelesaikan segala bentuk problematika dalam kehidupan. Al-Qur'an dan hadis sampai saat ini masih terawat, baik isi dan maknanya, sehingga hal ini menjadi suatu yang tegas bagi generasi selanjutnya untuk mengatur skala prioritasnya.

Penelitian ini bertujuan untuk menjelaskan tata cara mengatur skala prioritas dalam kehidupan manusia menurut fondasi ajaran Islam. Untuk sampai pada tujuan tersebut, penelitian ini menggunakan metode deksriptif-kualitatif dengan teknik studi kepustakaan, yaitu dengan mengumpulkan data dari berbagai macam informasi baik dari jurnal, artikel, buku, dan majalah ${ }^{5}$. Pendekatan tematik juga digunakan dalam proses penulisan ini, yaitu dengan melihat ayat-ayat Al-Qur'an yang membahas topik tertentu, sesuai dengan masa turunnya, sebab-sebab turunnya, kemudian memperhatikan ayat-ayat tersebut dengan penjelasan, keterangan hubungannya dengan ayat lain, kemudian mengistinbatkan makna dibalik fakta ${ }^{6}$. Dengan pendekatan tematik ini, ayat-ayat Al-Qur'an yang berkaitan dengan manajemen dapat dijadikan acuan dalam mengatur skala prioritas dalam ajaran Islam. Penelitian ini memanfaatkan metode double movement yaitu suatu gerakan ganda, dimana gerakan ini memperhatikan situasi sekarang dengan bercermin ke masa Al-Qur'an diturunkan, kemudian gerakan kembali ke masa sekarang. Metode ini bisa dilakukan dengan membawa problem-problem umat untuk dicarikan solusinya pada Al-Qur'an atau

\footnotetext{
4 Imat Maftuhah, "Pemikiran Ijtihad Syekh Yusuf Qordhawi," Tazkiya Jurnal Keislaman, Kemasyarakatan \& Kebudayaan 19, no. 1 (2014): 95-105.

5 Abdi Mirzaqon, "Studi Kepustakaan Mengenai Landasan Teori Dan Praktik Konseling Expressive Writing Library," Jurnal BK UNESA 8, no. 1 (2018): 1-8.

6 Maragustam, "Paradigma Revolusi Menta Dalam Pembentukan Karakter Bangsa Berbasis Sinergitas Islam Dan Filsafat Pendidikan,” Jurnal Pendidikan Agama Islam XII, no. 2 (2015): 161-76.
} 
memaknai Al-Qur'an dalam konteksnya dan memproyeksikannya kepada situasi sekarang ${ }^{7}$.

Sebagai penguat, dibutuhkan sebuah kajian literatur yang berkaitan dengan penelitian ini, salah satunya adalah karya Muammar M. Bakry dengan judul "Asas Prioritas dalam al-Maqashid al-Syariat". Persamaan dengan penulisan tersebut adalah membahas tentang skala prioritas kehidupan. Perbedaannya adalah bahwa pada tulisan ini skala prioritasnya menggunakan acuan al-Maqāșid al-Syarī'ah atau sesuai dengan tujuan-tujuan yang ditetapkan oleh agama dalam mewujudkan kemaslahatan. Posisi tulisan ini adalah sebagai pelengkap dari karya-karya sebelumnya, sehingga dapat dijadikan bahan pengembangan teori-teori yang berguna bagi kalangan akademisi dan khalayak umum untuk diaplikasikan pada kehidupan sehari-hari.

Selanjutnya, penulis menggunakan penalaran deduksi, yaitu cara berpikir atau kerangka berpikir yang bertolak dari sebuah asumsi atau pernyataan yang bersifat umum untuk mencapai sebuah kesimpulan yang bersifat khusus. Deduksi sering disebut dengan logika minor karena mendalami penyesuaian pikiran dengan hukum, aturan dan patokan tertentu ${ }^{9}$.

\section{PEMBAHASAN}

\section{Manajemen Skala Prioritas}

Beberapa macam makna dari manajemen yaitu, pertama, manajemen adalah suatu kelompok yang mengarahkan orang lain dengan proses kerja sama untuk mencapai tujuan. Kedua, manajemen adalah proses dalam mencapai tujuan organisasi secara efektif dan efisien pada lingkungan yang berubah-ubah dengan sumber daya terbatas melalui proses kerja sama. Ketiga, manajemen adalah proses perencanaan, pengorganisasian, pengarahan, dan pengendalian yang terkoordinir oleh semua sumber daya untuk mencapai tujuan yang ditentukan. Keempat, manajemen adalah orang yang bekerja pada organisasi formal dapat menciptakan lingkungan yang efektif. Kelima, manajemen mengkoordinir suatu kegiatan yang dilakukan sekelompok orang untuk mencapai tujuan yang tidak dapat dicapai seorang saja. Keenam, manajemen adalah proses untuk mencapai tujuan organisasi dengan perencanaan, pengorganisasian, pengarahan, pengendalian, aktivitas anggota organisasi, dan kegiatan yang menggunakan semua sumber daya organisasi. Ketujuh, manajemen adalah proses untuk mencapai tujuan organisasi secara efektif dan efisien melalui perencanaan, pengorganisasian, pengarahan, serta pengendalian sumber daya manusia dan sumber daya ${ }^{10}$.

Merujuk pada kbbi.kemendikbud.go.id, skala merupakan lajur yang dapat digunakan untuk mengukur tingkat atau banyaknya suatu perbandingan besarnya gambar dan sebagainya dengan keadaan yang sebenarnya. Skala menjadi parameter dalam menentukan suatu ukuran, sehingga dengan skala, manusia dapat mengetahui

7 Prof. Dr. Sutrisno, Fazlur Rahman Kajian Terhadap Metode, Epistimologi Dan Sistem Pendidikan (Yogyakarta: Pustaka Pelajar, 2006).

${ }^{8}$ Muammar M. Bakry, “Asas Prioritas Dalam Al-Maqashid Al-Syari'ah,” Al-Azhar Islamic Law Riview 1, no. 1 (2019): 1-8.

${ }^{9}$ Mundiri, Logika (Jakarta: Raja Grafindo Persada, 2000).

${ }^{10}$ Mamduh Hanafi, Konsep Dasar Dan Perkembangan Teori Manajemen, Modul, vol. 1, 2015, http://repository.ut.ac.id/4533/1/EKMA4116-M1.pdf. 
gambaran suatu objek. Prioritas merupakan arti kata dari al-awlawiyyat diambil dari kata awla yang bermakna lebih utama dan lebih penting ${ }^{11}$. Berdasarkan makna-makna tersebut maka skala prioritas merupakan rangkaian data, kegiatan atau aktivitas bermacam-macam yang tersusun berdasarkan tingkat kepentingan dan kebutuhan yang utama sampai dengan kebutuhan yang tidak utama, dari yang pokok sampai yang umum, dari hal primer sampai dengan sekunder, sehingga dapat dipilih atau dikerjakan sesuai urutan tersebut.

\section{Prioritas dalam Ajaran Islam}

Pandangan Islam dalam meninjau prioritas dapatlah ditelaah melalui fikih prioritas sebagai pemahaman yang komprehensif berkaitan dengan hukum, nilai dan amalan agama serta menempatkannya dalam tingkatan yang adil. Hal itu dengan mendahulukan yang lebih penting (aham) daripada yang penting (muhim), yang lebih utama (afdal) di atas yang utama ( $f a d \underline{\imath} l$ ), primer (daruriyyāt) di atas sekunder (hajjiyyāt) dan lain sebagainya. Asumsinya, dengan menempatkan segala aturan hukum, nilai dan amalan agama itu pada skala prioritas secara fair dan adil, maka tatanan kehidupan yang harmonis dan seimbang akan tercipta di tengah-tengah masyarakat ${ }^{12}$. Sejatinya, ihwal beban pemberian kewajiban, nilai da pelaksanaan hukum dalam agama Islam terdapat perbedaan satu dengan yang lainnya. Semua memiliki tingkat yang berbeda, mulai dari yang kecil kepada yang besar, mulai dari yang pokok kepada yang cabang, serta dapat berbentuk rukun sampai berkedudukan sebagai pelengkap. Pada setiap permasalahan juga terdapat kedudukan yang utama atau esensi terdapat persoalan pinggiran atau bahkan persoalan yang tidak signifikan ${ }^{13}$. Hal tersebut merupakan susunan prioritas dalam pandangan Islam serta diperkuat dengan pandangan Yusuf Qardhawi dengan fikih prioritasnya antara lain:

\section{Ukuran Kebenaran yang Disorot oleh Al-Qur'an}

Terdapat isu-isu yang dapat dirujuk dari Al-Qur'an untuk menjelaskan di antara ukuran yang paling benar. Ayat-ayat Al-Qur'an sering mengulang mengenai penegasan suatu hal yang diperintahkan dan dilarang berupa janji dan ancaman yang perlu diketahui. Seperti iman kepada Allah swt. yang harus diberikan perhatian dan diutamakan dalam persoalan tingkah laku, penilaian, pemikiran, meneladani para nabinabi-Nya, surga dan neraka, pahala dan siksaan, hingga menyangkut persoalan hari akhirat. Pada contoh lainnya, pada pokok-pokok ibadah dapat ditinjau mulai dari mendirikan salat, zikir kepada Allah swt., zakat, menunaikan puasa, menjalankan haji, bertasbih, bertahmid, beristigfar, bertawakal, bertobat kepada-Nya, menghadirkan rasa takut terhadap azab-Nya, rahmat-Nya yang diharapkan, bersabar terhadap cobaanNya, bersyukur terhadap nikmat-nikmat-Nya, hingga jalan menuju nilai ketuhanan yang tinggi dan ibadah-ibadah batiniah ${ }^{14}$.

Pada keutamaan akhlak mulia, yang paling pokok adalah pemurah, kejujuran, kelembutan, rasa malu, kebenaran, kesederhanaan, ketulusan, mengasihi orang yang

${ }^{11}$ Husni Mubarrak A. Latif, "Studi Fiqh Prioritas Dalam Sunnah Nabi," Jurnal Ilmiah AlMu'ashirah 16, no. 1 (2019): 22, https://doi.org/10.22373/jim.v16i1.5738.

12 A. Latif.

${ }^{13}$ Yusuf Qardawi, Fiqh Prioritas (Jakarta: Robbani Press, 1996), https://www.darulkautsar.net/.

${ }^{14}$ Qardawi. 
lemah, berbuat baik kepada kedua orang tua, silaturahmi, menghormati tetangga, memelihara orang miskin, anak yatim dan orang yang sedang dalam perjalanan. Kita juga perlu mengetahui isu-isu yang proporsinya tidak begitu diperhatikan dalam Islam, kecuali sangat sedikit, misalnya masalah Isra' Nabi saw. Al-Qur'an hanya membicarakannya dalam satu ayat saja, berbeda dengan peperangan yang dibicarakan oleh Al-Qur'an di dalam satu surat penuh. Al-Qur'an juga tidak membicarakan mengenai maulid atau istilah lain yakni milad Rasulullah saw., sehingga ini yang menjadi dasar bahwa persoalan ini tidak diutamakan dalam kehidupan beragama Islam dan tidak terdapat keterkaitan dengan mukjizat, sebagaimana ajaran agama yang memiliki keterkaitan pada kelahiran al-Masih. Tidak terdapat anjuran mengenai ibadah atau amalan yang berkaitan dengan maulid. Sebagai landasan suatu ukuran yang benar, Al-Qur'an sebagai sumber ajaran Islam telah terdapat penjelasan sebagai fungsi pelengkap keterangan berupa sunah Nabi Muhammad saw. ${ }^{15}$.

\section{Perkara Pokok Atas Perkara Cabang dalam Memprioritaskannya}

Persoalan utama atas perkara cabang menjadi perhatian utama dalam perkara prioritas. Mendahulukan persoalan-persoalan utama yakni mengedepankan hal-hal yang berkaitan dengan tauhid dan keyakinan kepada Allah swt., iman yang ditujukan pada para malaikat-Nya, ditujukan pada pedoman berupa kitab-kitab suci-Nya, para rasul-Nya, dan kejadian pada hari akhir, yang dikatakan sebagai rukun iman sebagaimana dijelaskan oleh Al-Qur'an. Q.S. al-Baqarah: 177, yang berbunyi,

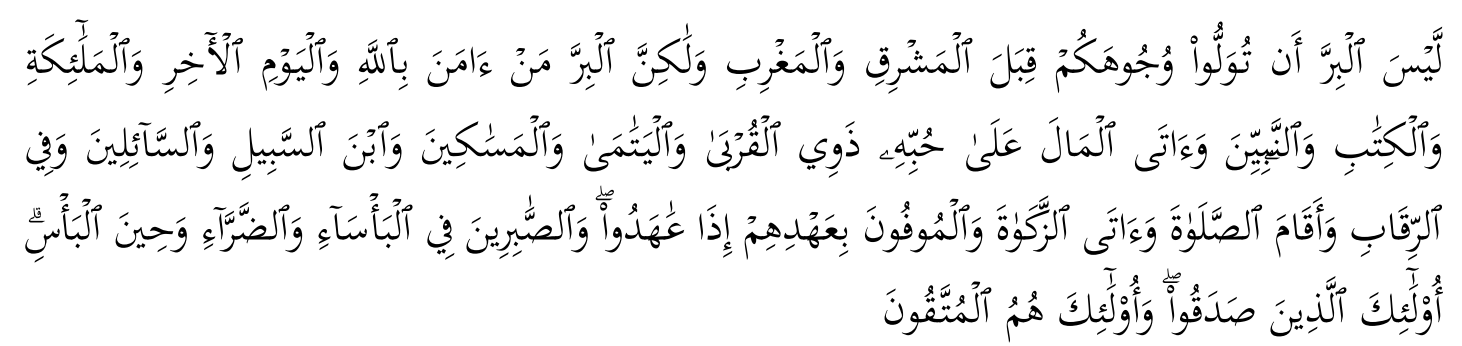

Terjemahnya:

Bukanlah menghadapkan wajahmu ke arah timur dan barat itu suatu kebajikan, akan tetapi sesungguhnya kebajikan itu dialah beriman kepada Allah, hari kemudian, malaikat-malaikat, kitab-kitab, nabi-nabi dan memberikan harta yang dicintainya kepada kerabatnya, anak-anak yatim, orang-orang miskin, musafir (yang memerlukan pertolongan) dan orang-orang yang memintaminta; dan (memerdekakan) hamba sahaya, mendirikan salat, dan menunaikan zakat; dan orang-orang yang menepati janjinya apabila dia berjanji, dan orangorang yang sabar dalam kesempitan, penderitaan dan dalam peperangan. Mereka itulah orang-orang yang benar (imannya); dan mereka itulah orangorang yang bertakwa.

Iman kepada takdir tidak ada disebutkan pada ayat yang mengandung pokok akidah, karena sesungguhnya iman yang ditujukan kepada Allah swt., babnya juga termasuk meyakini adanya takdir. Kesempurnaan pada ilahi yang diyakini juga bagian

${ }^{15}$ Qardawi. 
dari percaya akan ketetapan serta kehendak-Nya yang luas, segala ilmu yang dimilikiNya, dan kepastian akan kekuasaan-Nya. Keyakinan merupakan suatu perkara yang utama, sedangkan aplikasi amalannya merupakan perkara cabang. Sama halnya dengan akidah yang merupakan masalah pokok, sedangkan syariat adalah perkara cabang. Amalan yang baik harus didasari oleh keimanan yang benar. Sejauh apa pun amal perbuatan yang dilakukan seseorang, maka sejauh itu pula keimanan dimiliki oleh seseorang, dan sejauh itu pula dia melakukan perintah yang diberikan kepadanya, serta menjauhi larangan-Nya. Nilai amal perbuatan akan sia-sia di sisi Allah swt. jika tidak dilandasi dengan iman yang benar. Oleh karena itu, meluruskan akidah adalah perkara yang utama untuk didahulukan sehingga dapat memurnikan tauhid, memberantas kemusyrikan dan khurafat, mengokohkan benih-benih keimanan dalam hati, yang dapat membuahkan hasil untuk dinikmati dengan izin dari Tuhannya berupa kalimat tauhid, "Là ilāha illa Allāh," dapat bersemayam di dalam jiwa, menjadi cahaya hidup, menerangi gelapnya pemikiran manusia dan kegelapan perilakunya ${ }^{16}$.

\title{
Prioritas Hak Masyarakat Atas Hak Individu
}

Hak masyarakat sebagai hak umum serta hak pribadi sebagai hak individu merupakan suatu bahasan prioritas yang diperhatikan keutamaannya. Hak umum lebih didahulukan kewajibannya atas kewajiban pribadi. Setiap pribadi manusia membutuhkan dorongan dari khalayak umum, karena pada dasarnya sifat sosial terdapat pada setiap manusia, sehingga akan melekat rasa bermasyarakatnya ${ }^{17}$. Sebagai makhluk sosial, ia tidak akan bernilai jika manusia cenderung dengan kesendiriannya, sebalikanya dengan bermasyarakat akan tampak banyak nilai kemanusiaannya, baik dengan gotong royong, rasa kepedulian bahkan fakta dalam memilih pemimpin juga membutuhkan peran masyarakat. Dapat dibayangkan ketika seseorang hanya hidup sendirian, hidupnya akan terasa hampa, bahkan seorang Nabi Adam a.s. pun dengan segala kebaikan dan ketakwaannya juga membutuhkan rekan (relasi). Hal tersebutlah yang menjadikan manusia memiliki peran dalam bermasyarakat yang membuat keberadaan (eksistensi) seseorang. Atas dasar itu, kewajiban dalam memenuhi hak masyarakat umum lebih diutamakan daripada hak pribadi yang sifatnya individu.

\section{Implementasi Manajemen Prioritas dalam Ajaran Islam}

Manajemen Skala Prioritas (MSP) berarti merencanakan, mengorganisir, mengarahkan dan mengendalikan rangkaian data, kegiatan atau aktivitas yang sudah tersusun secara bertingkat, dari kebutuhan yang utama sampai dengan kebutuhan yang tidak utama, dari yang pokok sampai yang umum, dari hal primer sampai dengan sekunder. Dari berbagai teori yang dijabarkan sebelumnya, perlu dikembangkan sebuah formulasi untuk mencari solusi yang tepat dalam mengatur skala prioritas. Dengan demikian, beberapa hal yang terpenting dalam mengatur skala prioritas diabstraksikan di bawah ini.

\section{Fondasi dalam Skala Prioritas Menurut Ajaran Islam}

\author{
16 Qardawi. \\ 17 Qardawi.
}


Fondasi dalam mengatur skala prioritas sangat diperlukan sebagai landasan dilakukannya kegiatan atau aktivitas tersebut. Dalam hal fondasi, yang terkuat adalah dua sumber pedoman dalam Islam, yakni Al-Qur'an dan Hadis. Q.S. An-Nahl: 89, berbunyi,

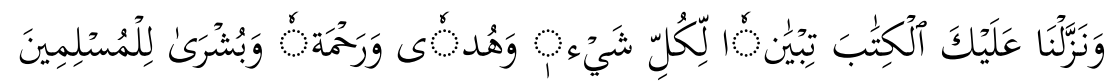

Terjemahnya:

Dan Kami turunkan kepadamu Al-Kitab (Al-Qur'an) untuk menjelaskan segala sesuatu dan petunjuk serta rahmat dan kabar gembira bagi orang-orang yang berserah diri.

Ayat di atas menegaskan pentingnya Al-Qur'an menjadi fondasi bagi setiap permasalahan. Dalam Tafsir al-Azhar dijelaskan bahwa ayat tersebut menyebutkan bahwa, "Nabi Muhammad saw. telah datang membawa keterangan lengkap dengan kitab Al-Qur'an itu. Apa saja keperluan kaum muslimin, telah cukup dijelaskan di dalamnya, mulai dari urusan dunia dan akhiratnya, sampai urusan nikah dan faraid, urusan perang dan damai, pemerintahan dan musyawarah, ibadat dan muamalat, petunjuk menempuh jalan yang diridai Allah swt., dan rahmat untuk persaudaraan sesama manusia, hingga khabar gembira, yaitu janji surga bagi umat Islam." 18

Al-Qur'an dan hadis merupakan pegangan utama umat Islam. Hal tersebut sesuai dengan hadis Nabi saw. yang diriwayatkan oleh Muslim, Abu Daud, dan Ibnu Majah, yang berbunyi,

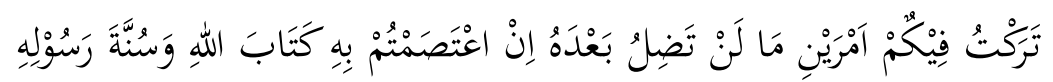

Artinya:

Telah Aku tinggalkan untuk kalian dua perkara di mana kalian tidak akan tersesat selamanya yaitu Al-Qur'an dan sunah Rasulullah.

Dari hadis tersebut tampak jelas bahwa posisi Al-Qur'an dan hadis memiliki peran yang teramat penting dalam mendorong umat Islam untuk maju jauh melampaui umatumat yang lainnya ${ }^{19}$. Setiap pekerjaan, kegiatan, status jabatan, bahkan konsep-konsep pendidikan apabila berlandaskan Al-Qur'an akan mendapatkan arah yang jelas. Seperti Presiden Turki yang mengubah negara tersebut menjadi negara yang mandiri, negara yang maju, dan terpenting adalah negara yang bernuansa Islami. Ini adalah salah satu contoh gambaran pemimpin yang menjadikan Al-Qur'ran sebagai sumber utama dalam menghadapi setiap perkara-perkara hidup yang kompleks dan mengatur skala prioritas, salah satu di antaranya dengan mengatur prioritas atas dasar fikih prioritas, yang dijabarkan di bawah ini.

\section{Mengatur Prioritas atas Dasar Fikih Prioritas}

${ }^{18}$ Abdul Malik Abdul Karim Amrullah, Tafsir Al-Azhar Jilid 5 (Jakarta: Pustaka Nasional PTE LTD Singapura, 1965). $23-34$.

${ }^{19}$ Aan Rukmana, “Kedudukan Akal Dalam Al-Qur'an Dan Al-Hadis," Mumtäz 1, no. 1 (2017): 
Dalam mengatur prioritas atas dasar fikih prioritas, prinsip-prinsip manajemen perlu diterapkan dalam mengaturnya, sebagaimana pada penjabaran di bawah ini.

\section{Perencanaan}

Rencana merupakan rancangan awal dalam melaksanakan kegiatan, sehingga setiap aktivitas memiliki rancangan awal. Jika ditinjau dari fikih prioritas, perencanaan dapat dijabarkan sebagaimana pada tabel berikut.

Tabel 1

Perencanaan Prioritas

\section{Fikih Prioritas}

\section{Perencanaan}

Ukuran kebenaran yang Disorot Al- Perencanaan disusun sesuai urutannya. AlQur'an Qur'an telah menegaskan beberapa perkara yang penting dalam urutan perilaku seperti contoh, rukun Islam yang diutamakan adalah mengucapkan syahadat, tata cara salat dan urutan lainnya. Dalam hal prioritas perencanaan yang tepat dalam urutan pertama adalah niat baik. Setiap perkara ibadah dan akhlak yang disorot Al-Qur'an tentu diawali dengan niat, sehingga dalam merencakan sesuatu harus dikuatkan dahulu niat yang baik

Perkara Pokok Atas Perkara Cabang Perencanaan disusun sesui urgensinya. Dalam menyusun rencana prioritas perlu adanya dasar-dasar tingkat urgensinya. Urgensi tertinggi menurut pandangan fikih prioritas adalah keutuhan tauhid dan keselamatan pada manusia, maka dalam perencanaan diperlukan susunan aturan seperti aturan beragama menciptakan toleransi, aturan lalu lintas terhindar dari kecelakaan serta aturan bersosial yang menciptakan kesejahteraan masyarakat.

Prioritas Hak Masyarakat Atas Hak individu
Perencanaan disusun sesuai kemaslahatan umum. Manusia sebagai makhluk sosial tentu membutuhkan kerjasama antar manusia. Dalam perencanaan prioritas, tentu meninjau seberapa besar prioritas tersebut berkontribusi kepada sekitar. Contoh dalam individu, menyusun perencanaan tidak pada saat gotong royong. Contoh dalam keluarga, memiliki rancangan anggaran untuk kebutuhan pangan, kebutuhan pendidikan, kebutuhan tempat tinggal, lalu kebutuhan rekreasi dengan menabung. Contoh dalam masyarakan umum terdapat rancangan skala besar maupun kecil 
seperti mengutamakan kesehatan, pendidikan, ekonomi, sosial serta teknologi.

\section{Pengorganisasian}

Pengorganisasian berarti pengaturan dan pembagian pekerjaan kepada setiap anggota sesuai kemampuan atau potensinya atau sesuai fungsi divisinya. Pandangan Stoner menyebutkan bahwa mengorganisir berarti terdapat kerjasama minimal dua orang dengan sistem kerja yang terstruktur untuk mencapai tujuan bersama ${ }^{20}$. Jika ditinjau dari fikih prioritas, pengorganisasian dapat dijabarkan sebagaimana pada tabel berikut.

Tabel 2

Prioritas dalam Mengorganisir

\begin{tabular}{|c|c|}
\hline Fikih Prioritas & Mengorganisir \\
\hline $\begin{array}{l}\text { Ukuran Kebenaran yang Disorot } \\
\text { Al-Qur'an }\end{array}$ & $\begin{array}{l}\text { Prioritas dikelompokkan berdasarkan urutan } \\
\text { sistematikanya. Menyusun prioritas tentu harus } \\
\text { memahami urutan yang tepat, sehingga dalam } \\
\text { melaksanakannya lebih mudah. Contoh dalam } \\
\text { pendidikan, terdapat kelompok jenjang sejak } \\
\text { dini, dasar, menengah dan tinggi. }\end{array}$ \\
\hline $\begin{array}{l}\text { Perkara Pokok Atas Perkara } \\
\text { Cabang }\end{array}$ & $\begin{array}{l}\text { Prioritas dikelompokkan berdasarkan } \\
\text { urgensinya. Mengelompokkan prioritas tentu } \\
\text { ditinjau seberapa besar urgensinya. Contohnya } \\
\text { dalam berkendaraan umum, tentu orang tua, ibu } \\
\text { hamil, disabilitas, dewasa dan anak-anak. }\end{array}$ \\
\hline Prioritas Hak Masyarakat Atas & Prioritas dikelompokkan berdasarkan \\
\hline Hak Individu & $\begin{array}{l}\text { kemaslahatan umum. Mengelompokkan } \\
\text { prioritas juga meninjau kebutuhannya. Contoh } \\
\text { yang mencolok pada masa pandemi, tentu } \\
\text { tenaga kesehatan menjadi kelompok utama } \\
\text { dalam mendapatkan vaksin daripada kelompok } \\
\text { lainnya. }\end{array}$ \\
\hline
\end{tabular}

\section{Pelaksanaan}

Bagian terpenting dalam manajemen adalah pelaksanaan, karena di dalamnya terdapat pengupayaan berbagai jenis tindakan itu sendiri, sehingga dalam suatu kelompok dari berbagai tingkatan, baik atasan maupun anggotanya akan berusaha melaksanakan pekerjaannya seoptimal mungkin untuk mencapai tujuan kepentingan kelompok tersebut dengan cara yang tepat dan benar $^{21}$. Pelaksanaan ini merupakan wujud dari rancangan yang sudah disusun secara sistematis. Menurut Hadari Nawawi, bimbingan berarti menjaga dan memelihara organisasi setiap personal, baik secara

${ }^{20}$ Aan Komariah Engkoswara, Administrasi Pendidikan (Bandung: Alfabeta, 2012).

${ }^{21}$ Abdul Goffar, "MANAJEMEN DALAM ISLAM (PERSPEKTIF AL- QUR'AN DAN HADITS)," Pendidikan Dan Keislaman 3, no. 1 (2018): 35-58. 
fungsional maupun struktural yang tersistem agar setiap pekerjaan yang sudah diusahakan dapat mencapai tujuannya. Kegiatan membimbing pada aktualisasinya juga dapat berupa pemberian perintah dan penjelasan serta pemberian petunjuk untuk melaksanakannya. Pada fikih prioritas dapat ditinjau pada tabel berikut.

Tabel 3

Prioritas dalam Pelaksanaan

\begin{tabular}{ll}
\hline Fikih Prioritas & \multicolumn{1}{c}{ Pelaksanaan } \\
\hline Ukuran Kebenaran yang Disorot Al- & Prioritas dilaksanakan berdasarkan urutan \\
Qur'an & yang sistematis. Dalam hal ibadah seperti salat, \\
& tentu sudah terstruktur urutannya mulai dari \\
& takbir sampai dengan salam. Begitu juga \\
& dalam khalayak umum, dalam pekerjaan \\
& menjadi seorang guru sudah jelas mulai dari \\
& mengajar sampai dengan menguji, dari \\
& pebisnis mulai dari modal sampai dengan \\
& pemasaran, dari segi petani mulai dari \\
& menanam bibit sampai dengan panen. \\
\hline Perkara Pokok Atas Perkara Cabang & Prioritas dilaksanakan sesuai dengan \\
& urgensinya. Tingkat urgensi menjadi dasar \\
& utama dalam pelaksanaan prioritas. Contoh \\
& pada seorang dokter yang sedang menangani \\
& pasien, namun di sisi lain ada acara penting \\
& keluarga, sehingga ia tetap mementingkan \\
& pasien. Dalam keluarga juga kebutuhan \\
& pangan lebih diutamakan dari pada rekreasi, \\
& dalam pendidikan, pelajaran agama lebih \\
& diutamakan daripada pelajaran umum guna \\
membentuk karakter. & \\
\hline Prioritas juga ditinjau dari kemaslahatan \\
umum. Dalam melakukan sesuatu juga \\
diprioritaskan hal yang sesuai dengan \\
kemaslahatan bersama. Contoh kepala sekolah \\
yang merangkap sebagai mahasiswa S2 yang \\
juga memiliki keluarga, tentu akan menguras \\
banyak waktu, baik buat keluarga maupun \\
pekerjaannya, jika ditinjau dari kemaslahatan \\
tentu kebutuhan sekolah lebih diutamakan, \\
lalu keluarga, dan terakhir adalah kebutuhan \\
pribadinya sebagai mahasiswa S2. Sebagai \\
individu di suatu sekolah atau masyarakat, \\
tentu ia mengutamakan gotong royong, lalu \\
kerja kelompok, baru menyelesaikan tugas- \\
tugas mandiri \\
\hline Prioritas Hak Masyarakat Atas Hak
\end{tabular}




\section{Pengendalian}

Bagian manajemen yang mencakup pengendalian merupakan fungsi manajemen yang berupa kegiatan penilaian dan adanya koreksi, sehingga apabila ada kesalahan dalam kinerja anggota, dapat diarahkan ke jalan yang benar dengan maksud dan tujuan yang telah digariskan semula. Pengendalian diadakan agar pelaksanaan kerja memiliki jaminan yang sesuai dengan standar yang telah ditetapkan dalam perencanaan. Pengawasan atau pengendalian termasuk proses untuk memastikan bahwa aktivitas sebenarnya sesuai dengan aktivitas yang telah direncanakan. Proses pengendalian dapat melibatkan beberapa elemen yaitu: (1) menerapkan standar kinerja; (2) mengukur kinerja; (3) membandingkan unjuk kerja dengan standar yang ditetapkan; dan (4) mengambil tindakan korektif saat terdeteksi penyimpangan ${ }^{22}$. Pengendalian jika ditinjau dengan fikih prioritas dapat dilihat pada tabel berikut.

Tabel 4

Prioritas dalam Pengendalian

\begin{tabular}{|c|c|}
\hline Fikih Prioritas & Pengendalian \\
\hline $\begin{array}{l}\text { Ukuran Kebenaran Yang Disorot } \\
\text { Al-Qur'an }\end{array}$ & $\begin{array}{l}\text { Pengendalian prioritas berdasarkan urutan } \\
\text { yang tersusun. Tujuan pengendalian ini agar } \\
\text { tertib mulai dari perencanaan, } \\
\text { pengorganisiran, lalu pelaksanaannya. Fungsi } \\
\text { dari pengendalian ini tidak lain untuk } \\
\text { meminimalisir kesalahan dalam prioritasnya, } \\
\text { seperti dalam beribadah salat rutin, puasa } \\
\text { dijalankan, naik haji mampu namun kurang } \\
\text { dalam membayar zakat, sehingga hal tersebut } \\
\text { perlu diperbaiki karena urutannya zakat lebih } \\
\text { diutamakan, lalu baru kemudian mengerjakan } \\
\text { haji. Dalam bermasyarakat juga ketika anak } \\
\text { muda tidak menghormati orang tua, namun } \\
\text { baik sesamanya hal ini juga perlu diperbaiki. }\end{array}$ \\
\hline $\begin{array}{l}\text { Perkara Pokok Atas Perkara } \\
\text { Cabang }\end{array}$ & $\begin{array}{l}\text { Pengendalian prioritas berdasarkan urgensi. } \\
\text { Contoh yang paling tepat ialah degradasi } \\
\text { moral. Ketika disuatu masyrakat terdapat } \\
\text { ekonomi yang tidak stabil diserta degradasi } \\
\text { moral tingkahlaku, maka yang perlu } \\
\text { dikendalikan dan diperbaiki adalah degredasi } \\
\text { moral. }\end{array}$ \\
\hline $\begin{array}{l}\text { Prioritas Hak Masyarakat Atas Hak } \\
\text { Individu }\end{array}$ & $\begin{array}{l}\text { Pengendalian prioritas berdasarkan } \\
\text { kemaslahatan umum. Contoh yang tepat, } \\
\text { sebagai pemimpin dengan mempertahankan } \\
\text { aturan-aturan yang memudahkan masyarakat, } \\
\text { seperti layanan } 1 \text { pintu sehingga ketika } \\
\text { masyarakat ingin mengurus pajak, SIM, dan }\end{array}$ \\
\hline
\end{tabular}

${ }^{22}$ Abdul Goffar. 
kebutuhan administrasi lainnya itu lebih efektif dan efisien. Toleransi merupakan pengendalian prioritas utama bagi tempat tinggal yang beragam.

\section{KESIMPULAN}

Berdasarkan uraian di atas, dapat disimpulkan bahwa mengatur prioritas dalam kehidupan dapat menghasilkan pola hidup yang tepat sasaran, sehingga hidup berjalan lurus sesuai tujuan dan bermanfaat bagi lingkungan sekitar. Mengatur prioritas dalam perspektif Islam tentu memiliki pondasi dan pedoman agama yaitu Al-Qur'an dan sunah dengan prinsip fikih prioritas. Untuk itu, mekanisme manajemen dapat dimulai dari perencanaan, pengorganisiran, pelaksanaan, dan pengendalian yang diintegrasikan dengan prinsip fikih prioritas, yaitu ukuran kebenaran yang disorot dalam Al-Qur'an, prioritas pokok atas prioritas cabang, dan prioritas hak masyarakat atas hak inidividu. Dengan demikian, kajian ini mampu menghasilkan beberapa pandangan bahwa dalam mengatur prioritas harus berdasarkan sistematika urutan yang tepat, berdasarkan tingkat urgensi, dan berdasarkan seberapa besar skalanya bagi kemaslahatan umum.

\section{DAFTAR PUSTAKA}

A. Latif, Husni Mubarrak. "Studi Fiqh Prioritas Dalam Sunnah Nabi." Jurnal Ilmiah Al-Mu'ashirah 16, no. 1 (2019): 22. https://doi.org/10.22373/jim.v16i1.5738.

Aan Rukmana. "Kedudukan Akal Dalam Al-Qur'an Dan Al-Hadis." Mumtäz 1, no. 1 (2017): 23-34.

Abdul Goffar. "MANAJEMEN DALAM ISLAM (PERSPEKTIF AL- QUR'AN DAN HADITS)." Pendidikan Dan Keislaman 3, no. 1 (2018): 35-58.

Abdul Malik Abdul Karim Amrullah. Tafsir Al-Azhar Jilid 5. Jakarta: Pustaka Nasional PTE LTD Singapura, 1965.

Aditya Widya Putri. "Empati Diatas Tempat Duduk Prioritas KRL." Tirto.Id, November 11, 2016.

Celly Beto. "Prioritas Pendidikan Tahun 2021, Menurut Menteri Pendidikan Dan Kebudayaan Nadiem Makarim." https://www.depoedu.com/2020/08/31/edutalk/prioritas-pendidikan-tahun-2021-menurut-mentri-pendidikan-dan-

kebudayaan-nadiem-

makarim/\#: :text=Prioritas\%20Pendidikan\%20adalah\%20proses\%20penentuan, target\%20pendidikan\%20akan\%20dapat\%20tercapai., 2020.

Dendy Sugono. Kamus Bahasa Indonesia. Jakarta: Pusat Bahasa, 2008.

Engkoswara, Aan Komariah. Administrasi Pendidikan. Bandung: Alfabeta, 2012.

Hanafi, Mamduh. Konsep Dasar Dan Perkembangan Teori Manajemen. Modul. Vol. 1, 2015. http://repository.ut.ac.id/4533/1/EKMA4116-M1.pdf.

Imat Maftuhah. "Pemikiran Ijtihad Syekh Yusuf Qordhawi." Tazkiya Jurnal Keislaman, Kemasyarakatan \& Kebudayaan 19, no. 1 (2014): 95-105.

Maragustam. "Paradigma Revolusi Menta Dalam Pembentukan Karakter Bangsa Berbasis Sinergitas Islam Dan Filsafat Pendidikan." Jurnal Pendidikan Agama Islam XII, no. 2 (2015): 161-76.

Mirzaqon, Abdi. "Studi Kepustakaan Mengenai Landasan Teori Dan Praktik 
Konseling Expressive Writing Library.” Jurnal BK UNESA 8, no. 1 (2018): 1-8. Muammar M. Bakry. "Asas Prioritas Dalam Al-Maqashid Al-Syari'ah." Al-Azhar Islamic Law Riview 1, no. 1 (2019): 1-8.

Mundiri. Logika. Jakarta: Raja Grafindo Persada, 2000.

Prof. Dr. Sutrisno. Fazlur Rahman Kajian Terhadap Metode, Epistimologi Dan Sistem Pendidikan. Yogyakarta: Pustaka Pelajar, 2006.

Qardawi, Yusuf. Fiqh Prioritas. Jakarta: Robbani Press, 1996. https://www.darulkautsar.net/. 